УДК 82I.ІІІ

ББК 83.3(4Вел)
«А БУДУЩЕЕ ТАИЛОСЬ В ПРОШЕДШЕМ» :

О МЕХАНИЗМЕ ДВИЖЕНИЯ ПОЭЗИИ

БРИТАНСКОГО МОДЕРНИЗМА

ОТ Т.С. ЭЛИОТА К ТЕДУ ХЬЮЗУ

(C) 2017 г. Т.Н. Красавченко

Институт научной информации по общественным наукам (ИНИОН) Российской академии наук, Москва, Россия

Дата поступления статьи: го апреля 2017 г.

Дата публикации: 25 сентября 2017 г.

DOI: I0.22455/2500-4247-20I7-2-3-74-8I

Аннотация: В статье выявляется связь поэтов казалось бы совершенно разных творческих индивидуальностей и эпох. Тед Хьюз (1930-1998) - широко признанный в Великобритании и за ее пределами поэт-натурфилософ второй половины XX в., его интересует противостояние Природы и человека, самоубийственно разрушающего Природу. Т.С. Элиот (I888-І965) - реформатор англоязычной модернистской поэзии, поэт городской цивилизации. В его время поэзия «Природы» существует, но уходит на второй план, в тень, хотя представлена даже в творчестве самого Элиота, в его «Пейзажах» - стихотворениях, написанных в начале г93о-х гг. Элиота и Хьюза объединяет то, что оба они - поэты-модернисты. Элиот стоит у начала модернизма, Хьюз - у его конца, хотя он жил уже в период расцвета постмодернизма, однако постмодернистом не был, ибо не занимался деконструкцией, дроблением «модели мира». И Элиот, и Хьюз - поэты эсхатологической направленности, поэты мифологи. Как и Элиот, Хьюз - традиционалист, хотя Элиот, американец, был «осознанным традиционалистом», а Хьюз, англичанин, - скорее традиционалист интуитивный, прирожденный. Элиота нет в его «великой традиции», ибо его время - время отрицания Элиота, вызванного закономерной сменой «мейнстримов»: во второй половине XX в. британская поэзия «устала» от урбанизма, от «пренебрежения Природой» и вернулась «на круги своя», и, что у Элиота было на периферии творчества, в поэзии Хьюза выходит на первый план.

ключевые слова: британская поэзия, модернизм, Т.С. Элиот, Тед Хьюз, традиционализм, мейнстрим, постмодернизм.

Информация об авторе: Татьяна Николаевна Красавченко - доктор филологических наук, ведущий научный сотрудник, Институт научной информации по общественный наукам Российской академии наук, Нахимовский просп., д. 5I/2I, II7997 Москва, Россия.

E-mail: tatianakras@mail.ru 


\section{"AND TIME FUTURE CONTAINED IN TIME PAST": BRITISH MODERNIST POETRY FROM T.S. ELIOT TO TED HUGHES}

This is an open access article distributed under the Creative Commons Attribution 4.0 International (CC BY 4.0)
(C) 20I7. T.N. Krasavchenko Institute of Social Sciences Information of the Russian Academy of Sciences, Moscow, Russia Received: April IO, 2017 Date of publication: September 25, 2017

Abstract: It seems that T.S. Eliot (I888-I965) and Ted Hughes (I930-I998) are poets of different individual talents and epochs. Hughes, a poet of the second half of the $20^{\text {th }}$ century, concentrated on the conflict between Nature and the human being destroying Nature and thus preparing the end of the humanity. T.S. Eliot was a poet of urban civilization, a reformer of the Anglophone modernist poetry. In his days, the "poetry of Nature" rooted in the pastoral poetry of the $17^{\text {th }}-18^{\text {th }}$ centuries and in Romanticism, existed but only at the margins of mainstream poetic trends. Nevertheless, one can find it even in Eliot's poetry, particularly in his Landscapes - poems written at the beginning of the I930s. Also, both Eliot and Hughes were modernists. Eliot standing at the beginning of modernism, Hughes at its end; though the latter lived in the time of postmodernism, he was not a postmodernist himself since he was not engaged in the deconstruction and fragmentation of the "world model." Like Eliot, he was a poet with integral Weltanschauung and a bright individual talent. Like Eliot, he was a traditionalist, though Eliot being an American was a "conscious traditionalist," while Hughes, an Englishman, was most likely a "born" traditionalist: instead of deconstructing tradition, he was bearing on it. His "great tradition" included Shakespeare, Blake, Coleridge, Kipling, Graves, and Dylan Thomas. Both Eliot and Hughes are poets of eschatological trend and mythologists. However, one will not find Eliot among the authorities enlisted by Hughes in his "great tradition." In the time of Hughes, Eliot was rejected due to the regular change of mainstreams trends. British poetry in the second half of the $20^{\text {th }}$ century is "tired" of urban poetry, of "Nature denial," so it comes back to its track, and the motives that existed in Eliot's poetry only in the background are now brought to the forefront.

Keywords: British poetry, modernism, T.S. Eliot, Ted Hughes, mainstream, traditionalism, postmodernism.

Information about the author: Tatiana N. Krasavchenko, DSc in Philology, Leading Research Fellow, Institute of Social Sciences Information (INION) of the Russian Academy of Sciences, Nakhimovsky av. 5I/2I, II7997 Moscow, Russia.

E-mail: tatianakras@mail.ru 
Типология возникновения модернизма в Англии - та же, что и в других странах. Адрес во времени - начало XX в., ключевые события - Первая мировая война; типологические черты: отказ от антропоцентризма; ремифологизация истории, восприятие времени не как линейного, поступательного феномена, а как единого ряда - прошлого-настоящего-будущего, в пространственной перспективе, сосредоточенность на сознании человека, т. е. «интернизация мира».

Однако у британского модернизма была и своя специфика - это прежде всего роль «пришельцев». Вирджиния Вулф и группа «Блумсбери» играли в модернизме свою роль, но наиболее радикальные новации принадлежали «пришельцам», американцам - Эзре Паунду и, главным образом, Т.С. Элиоту, ирландцам Джеймсу Джойсу и У.Б. Йеитсу, хотя следует учесть: идеологом британского модернизма был неоклассицист англичанин Томас Эрнст Хьюм.

Но то, что общеевропейская эстетическая революция проходила в английской поэзии и, шире, английской литературе начала XX в. под «флагом традиционализма» [2, с. 328] было в значительной мере делом Э. Паунда и, главным образом, Т.С. Элиота, который в І9Іо-г920-е гг. ввел в английский критико-литературный обиход понятие «традиция» и разработал ее теорию, основанную на обостренном ощущении утраты связи времен, а в I930-І940-е гг. он развил как философию культуры.

То, что в Англии это сделали американцы, лишь на первый взгляд кажется парадоксом. Архетипные положения английского консерватизма, основы английского традиционализма сформулировали и обосновали еще британские философы конца XVIII в. - Д. Юм, Э. Бёрк, А. Смит, А. Фергюсон, считавшие общество организмом, развивающимся эволюционно. 
Истоки признанного традиционализма английской культуры - в отторжении феномена социальных революций, испытанных англичанами сначала на собственном опыте в XVII в., потом в качестве наблюдателей событий во Франции. Для англичан чувство традиции органично, оно у них «в крови», на уровне «инстинкта», именно поэтому они не сознают его, т. е. «говорят прозой», не сознавая этого. Американцам же, как заметил еще в I908 г. (в книге «Вино пуритан») американский литературовед В.В. Брукс, свойственно обостренное «чувство традиции», рожденное «комплексом неполноценности», вызванным отсутствием вековых традиций.

В Гарвардском университете, где Элиот в 1906-г909 гг. изучал философию и литературу, система гуманитарного образования ориентировала его на восприятие европейской культуры как целостного явления. Именно там и тогда наметился прочный, сохранявшийся всю жизнь круг его интересов Средневековье, Данте, английская литература XVII в., французские символисты. И в дальнейшем европейские увлечения Элиота проявлялись в форме, обычной для американца, воспринимающего Европу и ее культуру в более широкой перспективе, чем сами европейцы с их острым чувством национальных различий. И в сущности почти всё, что Элиот сделал в английской поэзии и критике, он сделал именно благодаря тому, что был представителем авангардной американской культуры в культуре традиционной, английской.

Таким образом, врожденный и привнесенный традиционализм уберег английский модернизм от крайностей авангардизма.

В литературоведении, зарубежном и отечественном, преувеличивается разрыв между экспериментаторством Элиота в поэзии и его консерватизмом, традиционализмом в критике. Тут следует учитывать тот факт, что впервые он опубликовал стихи - «Любовная песнь Дж. Альфреда Пруфрока» - в чикагском авангардистском журнале «Поэтри» в I9I5 г., а «Прелюдии», «Рапсодия ветреной ночи» - в авангардистском, вортицистском журнале Уиндема Льюиса «Blast» - «Взрыв». А как критик начал печататься в престижном английском литературном издании, приложении к газете «Таймс», где порой крайне оригинальные суждения был обязан выражать умеренно и бесстрастно, как того требовали правила этого еженедельника. Таким образом, сразу даже на поверхностном уровне - возникла видимость расхождения между 
его реноме поэта-авангардиста и репутацией традиционалиста в критике. На самом деле принципиального расхождения не было; скорее можно говорить об отличии «раннего» Элиота от «позднего», по сути же его творчество цельный, единый мир, создатель которого был вполне последователен. В его творчестве - поэзии, критике, в эссе о литературе и культуре - доминирует идея «динамической традиции», не только не противоречившей его новаторским реформам в поэзии, а, напротив, служившей их источником.

Он вошел в историю литературы и культуры XX в. как реформатор англоязычной поэзии, который на новом историческом этапе привел в соответствие формы поэтического выражения и урбанистическое мироощущение человека нового века, пережившего катастрофу войны. Объявив себя неоклассицистом, он отверг либерально-романтические представления о совершенствовании человека в ходе якобы целесообразного исторического процесса. Модернисты, по его замечанию (о Джойсе), «убили XIX век», что, прежде всего, означало отказ от «светлых», романтических иллюзий и новую философию человека и времени (хотя учитывая неоднородность XIX в., теперь ясно, что модернисты многое наследовали у него, допустим, тот же Т.С. Элиот у У. Вордсворта - из его теории языка поэзии). Для понимания природы британского модернизма того этапа важно то, что Элиот выступил как поэт-урбанист, поэт городской цивилизации. В его время традиция «поэзии Природы», истоки которой - в пасторальной поэзии XVI-XVIII вв., в сентиментализме, в романтизме (ее кульминации), сохраняется, но отходит на второй план, становится маргинальной. Более того, эта традиция представлена и в творчестве самого Элиота в «Пейзажах» (“Landscapes”), пяти стихотворениях, написанных им в начале І930-х гг. в США, но и они маячат где-то в глубине, не на авансцене его творчества; авансцена - это хорошо всем известные «Бесплодная земля», «Полые люди», «Пепельная среда», «Четыре квартета».

Но и традиция, и тема Природы принадлежат сфере английской национальной органики. На какое-то время урбанист Элиот затмевает, точнее, отодвигает «поэтов Природы», но неизбежно рано или поздно все возвращается на свои круги. Во второй половине XX в. в рамках философии и эстетики модернизма мы наблюдаем ренессанс «поэзии Природы» - главная траектория английской литературы приводит к неоромантизму - к ощущающему свою особую, «пророческую миссию» Теду Хьюзу (г930-г998). Подобно Вордсворту и Теннисону, он избран поэтом-лауреатом и вписыва- 
ется в один ряд с английскими поэтами-натурфилософами, однако Хьюзу свойственно свое видение натурфилософской темы, во многом переворачивающее представления об английской традиционной поэзии природы: его интересует прежде всего противостояние человека и природы, в его творчестве романтизм сочетается с модернизмом.

Конечно, романтическая идея природы вернулась в английскую литературу еще раньше, скажем, в творчестве «оптимистического пантеиста» [I, c. 485] антропоцентриста Дилана Томаса, но в творчестве Теда Хьюза она не просто возродилась, она сочеталась с модернистским антиантропоцентризмом. Творчество Хьюза, сформировавшееся в условиях апогея технократического общества и предельно прагматико-потребительского отношения к природе, представляет собой новый образец мифотворчества; его «ядро» восстановление магического взгляда на Природу. В его поэзии воплощен глубочайший, сформировавшийся в процессе развития цивилизации конфликт между человеком и Природой в широком смысле слова. «Человек в согласии с Природой» - идеал Хьюза, совпадающий с идеалом Вордсворта, но кардинально отличающийся в деталях осуществления этого идеала, ибо между ними лег XX в. Хьюз пришел к этому идеалу лишь в поздней поэзии, пережив этапы поклонения Природе и отрицания человека. Долгое время человек в его поэзии выступал как своего рода самоубийца, разрушающий Природу и энергично подготавливающий свой крах и конец. В рамках натурфилософской темы Хьюз создал беспощадную и трезвую поэтическую аналогию, возможно, «последнего кризиса», переживаемого человеком XX в. Живший в эпоху постмодернизма, Хьюз не был постмодернистом, не занимался деконструкцией традиции, он основывался на традиции. Его традиция - это Шекспир, Блейк, Кольридж, Киплинг, Роберт Грейвз, Дилан Томас.

В отличие от постмодернистов, которые деконструировали, дробили «модель мира», т. е. целостное представление о нем, и таким образом дробили «творческую индивидуальность», Хьюз - поэт с целостным мировоззрением, яркой творческой индивидуальностью.

Постмодернизму свойственна эрозия веры в «великие метаповествования», объясняющие и тем самым легитимирующие целостные представления о реальности. Поэзия же Хьюза, особый целостный мир, - это и есть «метаповествование», дающее «модель мира», что объединяет его с художниками-модернистами - Т.С. Элиотом, Уиндемом Льюисом. 
В английской критике (Терри Иглтон и др.) наметилась тенденция рассматривать не только Т.С. Элиота, но и модернизм вообще как «транскультурную имплантацию», как революцию, осуществленную не англичанами, а американцами и ирландцем Джойсом; в поэзии и поэтике Элиота видят чужеродное явление. Причина не в том, что он действительно чужероден английской традиции. Просто его «великая традиция», включавшая в себя, кроме Шекспира, елизаветинцев, английских поэтов-метафизиков, еще и Данте, и французских символистов, «сошла со сцены» и стала маргинальной.

Но вот, например, стихотворение:

Here the crow starves? Here the patient stag

Breeds for the rifle. Between the soft moor

And the soft sky, scarcely room

To leap or soar. Substance crumbles, in the thin air

Moon cold or moon hot. The road wind in

Listlessness of ancient war,

Langour of broken steel,

Clamour of confused wrong, apt

In silence...

[3, c. 204]

Здесь голоден ворон, здесь кроткий олень

Пригоден для пули. В пространстве неярком

Меж небом и вереском ловкий прыжок и полет

Ни к чему. В тонком воздухе лунный

Либо жар, либо лед. Путь колеблется между

Равнодушием вечной вражды

И апатией сломанных копий,

Между шумом греха и безмолвием зла....

(перевод М. Ерёмина) [3, с. 205]

Чье это стихотворение?

Попадись оно мне просто на листе бумаги, я бы решила, что это Тед Хьюз. Но это Т.С. Элиот. Один из его вышеупомянутых «Пейзажей» - 
«Рэннох, долина Гленкоу». В «Пейзажах» на свой лад намечается то, что достигнет кульминации в поэзии Хьюза.

Отрицание же Элиота, «пересмотр» авторитетов вызван, вероятно, общим, закономерным, периодически происходящим в литературе пересмотром «мейнстрима» в поэзии (и, шире, в литературе, культуре): к концу XX в. английская поэзия в рамках модернизма проделала свой путь: она устала от урбанизма, от «пренебрежения Природой», «искусственности» и вернулась «на круги своя».

\section{Список литературы}

I Коренева M.M. Тед Хьюз // Энциклопедический словарь английской литературы ХХ века / отв. ред. А.П. Саруханян. М.: Наука, 2005. С. 484-487.

2 Красавченко Т.Н. Эстетическое переживание пограничной эпохи в Англии и России: традиционализм и футуризм // Кануны и рубежи. Типы пограничных эпох типы пограничного сознания: в 2 ч. / отв. ред. В.Б. Земсков. М.: ИМЛИ РАН, 2002. Ч. II. C. $328-337$.

3 Элиот Т.С. Избранная поэзия. Поэмы, лирика, драматическая поэзия. Изд-е подг. Л. Аринштейн, С. Степанов. СПб.: Северо-Запад, 1994. 446 с.

4 Eliot T.S. Four Quartets. URL: https://www:davidgorman.com/4Quartets (Accessed Io April 20I7).

5 Hughes T. Selected Poems I957-I98I. London, Boston: Faber and Faber, 1982. 238 p.

\section{References}

I Koreneva M.M. Ted Hughes. Entsiklopedicheskiy slovar' angliiskoy literaturi XX veka [Encyclopedic Companion to English Literature], ed. by A.P. Sarukhanian. Moscow, Nauka Publ., 2005, pp. 484-487. (In Russ.)

Krasavchenko T.N. Esteticheskoye perezhivaniye pogranichnoy epokhi v Anglii i Rossii: traditsionalism i futurism [Aesthetic experience of a borderline epoch in England and Russia: traditionalism and futurism]. Kanuni I rubezhi. Tipi pogranichnikh epokh - tipi pogranichnogo soznaniya: $v 2 \mathrm{ch}$. [Eves and boundaries. Types of borderline epochs types of borderline consciousness: in 2 parts], ed. by V.B. Zemskov. Moscow, IMLI RAS Publ., 2002, part II, pp. 328-337. (In Russ.)

3 Eliot T.S. Izbrannaia poeziia. Poemy, lirika, dramaticheskaia poeziia [Selected Poetry. Poems, lyrics, dramatic poetry], sel. and edited by L. Arinshtein, S. Stepanov. St. Petersburg, Severo-Zapad Publ., I994. 446 p. (In Russ.)

4 Eliot T.S. Four Quartets. Available at: https://www:davidgorman.com/4Quartets (Accessed Io April 20I7). (In English)

5 Hughes T. Selected Poems 1957-I98r. London, Boston, Faber and Faber, I982. 238 p. (In English) 